\title{
Diversity, biomass, and carbon stock of understorey plants in the rubber agroforestry and rubber monoculture systems in Central Tapanuli District, North Sumatra, Indonesia
}

\author{
MUHDI $^{1, \boldsymbol{v}}$, DIANA SOFIA HANAFIAH ${ }^{2}$, RITA DESPRIANA BUTAR-BUTAR ${ }^{1}$ \\ ${ }^{1}$ Faculty of Forestry, Universitas Sumatera Utara. Jl. Tridharma Ujung No.1, Medan 20155, North Sumatra, Indonesia \\ Tel.: +62-61-8220605, Fax.: +62-61-8211920, "email: muhdisyehamad@yahoo.com \\ ${ }^{2}$ Faculty of Agriculture, Universitas Sumatera Utara. Jl. Prof. A. Sofyan No.3, Medan 20155, North Sumatra, Indonesia
}

Manuscript received: 9 May 2020. Revision accepted: 9 July 2020.

\begin{abstract}
Muhdi, Hanafiah DS, Butar-Butar RD. 2020. Diversity, biomass, and carbon stock of understorey plants in the rubber agroforestry and rubber monoculture systems in Central Tapanuli District, North Sumatra, Indonesia. Biodiversitas 21: $3508-3518$. Understorey vegetation plays an important role in carbon stock in forest. The objectives of the research were to identify the species of understorey, to find out the amount of carbon stored in the understorey, and to compare the understorey carbon stocks in rubber agroforestry and rubber monoculture. The research was done in Sijungkang Village, Andam Dewi Sub-district, District of Central Tapanuli and Forest Products Chemistry Laboratory, Faculty of Forestry, IPB University, Bogor, Indonesia on August-October 2016. The method used was the plant vegetation analysis of a stand and understorey. Destructive sampling method was used to harvest of understorey plant in $1 \mathrm{~m} \times 1 \mathrm{~m}$ sample plot. The carbon of understorey was analyzed by independent sample t-test. The results showed that there were 23 species in rubber agroforestry and 15 species in rubber monoculture. The understorey species dominant of rubber agroforestry was Stachytarpheta jamaicensis and rubber monoculture was Asystasia gangetica with important value index $30.64 \%$ and $33.01 \%$, respectively. The average understorey plant biomass in rubber monoculture was 0.94 tons/ha and in rubber agroforestry were 0.84 tons/ha, respectively. The carbon stocks of understorey in rubber agroforestry were 0.21 tons/ha and in rubber monoculture were 0.25 tons/ha, respectively. The result of t-test showed that there is not significant difference between carbon stock of understorey in rubber agroforestry and rubber monoculture.
\end{abstract}

Keywords: Agroforestry, biomass, carbon stock, monoculture, rubber tree, species diversity, understorey plant

\section{INTRODUCTION}

Climate change is an environmental issue faced by the Indonesian population. Human activities that damage forests, such as degradation and deforestation, can increase the release of carbon in the atmosphere (Houghton 2013; Maxwel et al. 2019). The element carbon (C) which binds with oxygen $\left(\mathrm{O}_{2}\right)$ in the atmosphere will form carbon dioxide $\left(\mathrm{CO}_{2}\right)$ gas. Carbon dioxide is a component of greenhouse gases (GHG) that causes climate change (Azham 2015). To enable suppress climate change, the existence of forests as carbon sinks must be maintained. Besides forests, agroforestry systems also play a role in carbon sequestration (Atanga et al. 2013; Pala et al. 2020).

Agroforestry systems have been implemented by several regions in Indonesia. The application of agroforestry systems is useful as a source of livelihood and control of climate change. Agroforestry is a technique offered for adaptation to global warming through its role in reducing landslides, reducing surface runoff and erosion, reducing nutrient loss through leaching, and maintaining biodiversity flora and fauna of the soil (Azhar et al. 2019).

All components of the vegetation in the agroforestry system, whether in the form of woody plants, agricultural crops, and plants that have the potential to absorb $\mathrm{CO}_{2}$ through photosynthesis. The process of photosynthesis produces carbohydrates stored in living plant parts (biomass), namely understorey plants, stems, branches, twigs, leaves, fruit, etc. Various plants that grow on agroforestry land store carbon stocks so that the agroforestry system is the right system in climate change mitigation strategies (Rijal 2019). Hairiah et al. (2011) stated that understorey plants include shrubs with stem diameter $<5 \mathrm{~cm}$, creeping plants, grasses or weeds. Underplant biomass is included in the carbon component above ground carbon. One of the studies on understorey carbon stocks showed that the average understory carbon in agroforestry in Pecekelan Village is 0.3 tons/ha and carbon in Kertayasa Village is 0.2 tons/ha (Rusolono 2006).

Biomass of the forest understorey was mainly related to the relative abundance and the trait values of the most dominant species. Functional diversity indices had impact on biomass (Wasof et al. 2018) and how the species composition in different forest strata influences ecosystem function (Chelli et al. 2019; Ya et al. 2019).

Rubber trees are now widely used as trees for agroforestry systems or used for or used to rehabilitate critical land or as reforestation plants (Yang et al. 2020). The combination of rubber trees with Shorea sp., Agathis dammara, Durio zibethinus, Aquilaria malaccensis, Garcinia atroviridis, Parkia speciosa, Archidendron 
pauciflorum, Theobroma cacao, and other tree and seasonal plants is a common sight and is found in many smallholdings in Sumatra, especially on sloping lands and around buffer zones of national parks or protected forests.

Sijungkang Village is one of the villages located in Andam Dewi Sub-district, Central Tapanuli District, North Sumatra Province, Indonesia. Based on data from the District Agricultural Leadership published in Central Bureau of Statistics Central Tapanuli (2016), Sijungkang Village has the largest rubber land in Andam Dewi Subdistrict. The area of rubber land in this village is 265 ha. In addition to rubber plants, other agricultural plants such as crops, vegetables, fruits are also found in this village. The combination of rubber and agricultural plants applied by the people of Sijungkang Village forms a rubber agroforestry system. Rubber monoculture system is also applied by the people in this village.

Agroforestry and rubber monoculture systems predicted to have high carbon stock. According to Chazdon (1998), understorey plant plays an important role in absorbing carbon. Therefore, research on the carbon stock of understorey plants on rubber agroforestry and monoculture land needs to be carried out to find out the importance of these understorey plants in storing carbon.

\section{MATERIALS AND METHODS}

\section{Study area}

The study was conducted in Sijungkang Village, Andam Dewi Sub-district, Central Tapanuli District, North Sumatra Province, Indonesia (Figure 1). The topography of Central Tapanuli District is mostly hilly with an altitude of 0-1.266 meters above sea level. Central Tapanuli region, $43,90 \%$ are hilly and bumpy. Andam Dewi is a sub-district in Central Tapanuli District, North Sumatra Province, Indonesia. Andam Dewi Sub-district is located on the west coast of Sumatra, $23^{0} 20^{\prime}-34^{0} 55^{\prime}$ NL and $65^{\circ} 58^{\prime}-76^{0} 36^{\prime}$ EL. Andam Dewi Sub-district is divided into thirteen villages, covering an area of $122.42 \mathrm{~km}^{2}$ (CBS Central Tapanuli 2012). Sijungkang Village is the widest village in Andam Dewi Sub-district, which is $23.71 \mathrm{~km}^{2}$. Sijungkang Village has the largest area of rubber land and rubber production in Andam Dewi Sub-district in 2015. The area of rubber land in Sijungkang Village is 265 ha with a production of 128 tons. The other agricultural products found in Sijungkang Village are coconut, cocoa and coffee. Sijungkang Village also produces crops, such as cassava, corn, sweet potatoes, peanuts, and green beans. In addition, Andam Dewi Subdistrict also produces fruits and vegetables (CBS Central Tapanuli 2016).

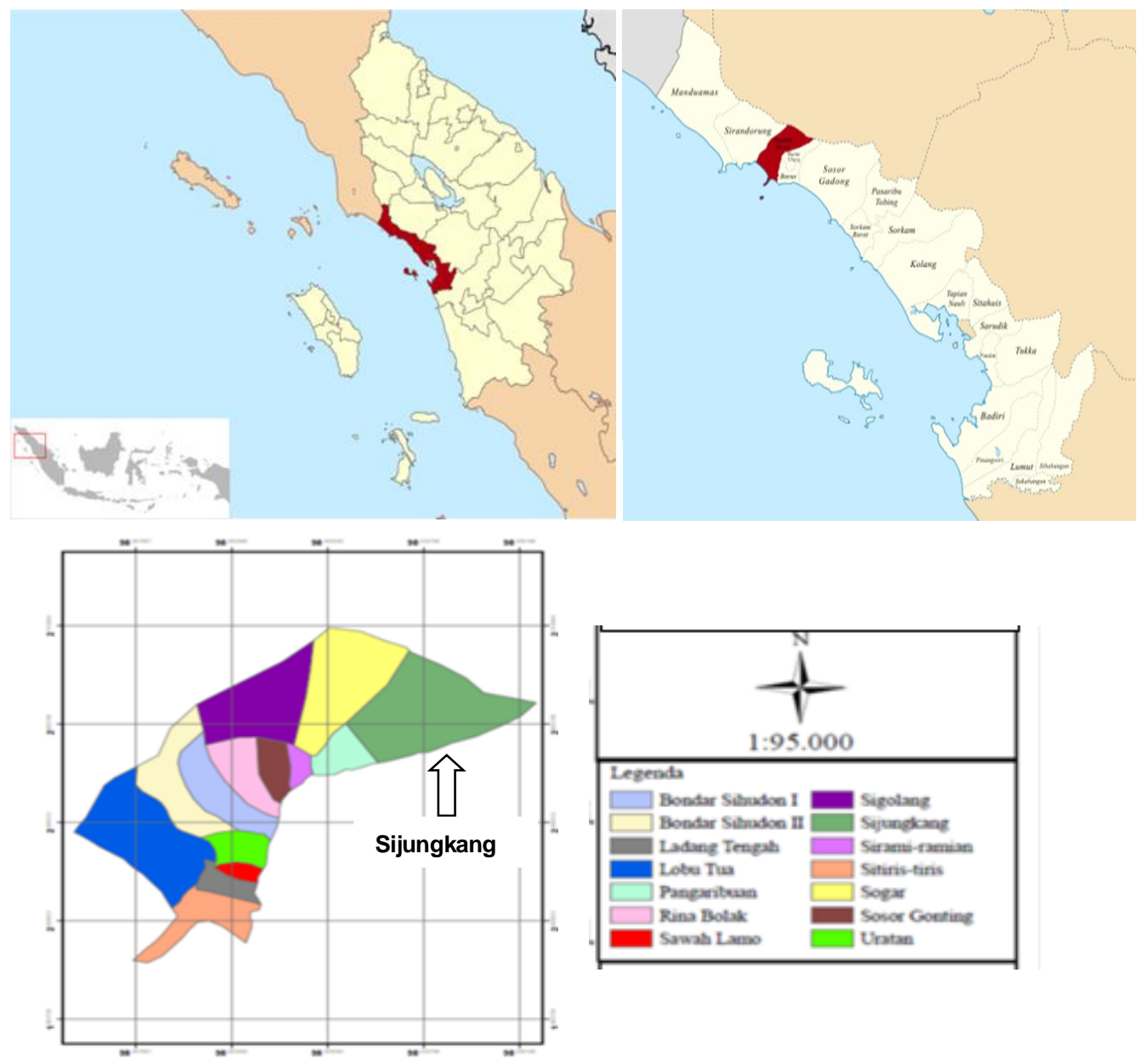

Figure 1. Map of research locations in Sijungkang Village, Andam Dewi Sub-district, Central Tapanuli District, North Sumatra, Indonesia 
Sijungkang Village is one of the villages in Andam Dewi Sub-district, Central Tapanuli District. This village has the largest rubber land in the district. This shows that the climatic and soil conditions are suitable for rubber plant growth. Rubber plants grow optimally in the lowlands with an altitude of $200 \mathrm{~m}$ asl. Optimal temperature needed ranges from $25^{\circ} \mathrm{C}$ to $35^{\circ} \mathrm{C}$ and optimal rainfall between $2500 \mathrm{~mm}$ to $4000 \mathrm{~mm} /$ year. Various types of soil can be in accordance with the conditions for growing rubber plants both young and old volcanic soils, even on peat soils $<2 \mathrm{~m}$ thick.

\section{Methods of research}

The study was carried out on rubber-based agroforestry and monoculture lands. The sample plot size used in this study is 0.72 ha. Rubber agroforestry and rubber monoculture each have an area of around 1.5 ha so that the sampling intensity obtained is $48 \%$. The determination of the sampling intensity is based on the Regulation of the Minister of Environment and Forestry of the Republic of Indonesia Number P.103/Menhut-II/2014 which states that the sampling intensity is at least $10 \%$. In both fields, 6 research sample plots were made, 3 sample plots in agroforestry land, and 3 sample plots in monoculture. The sample plot used is $40 \mathrm{~m} \times 60 \mathrm{~m}$ with a spacing of $1 \mathrm{~m}$. In each 3 sample plots were made with a size of $20 \times 20 \mathrm{~m}^{2}$ for an inventory of trees (diameter $\geq 20 \mathrm{~cm}$ ), $10 \times 10 \mathrm{~m}^{2}$ for pole inventory (diameter 10 to $<20 \mathrm{~cm}$ ), $5 \times 5 \mathrm{~m}^{2}$ for stake inventory (diameter $<10 \mathrm{~cm}$ and height $\geq 1.5 \mathrm{~m}, 2 \times 2 \mathrm{~m}^{2}$ for seedling inventory (height $\leq 1.5 \mathrm{~m}$ ) and $1 \times 1 \mathrm{~m}^{2}$ for an inventory of understorey (grass, herbs, and shrubs). Samples of observations were placed in a systematic sampling with random start. The sample plot design can be seen in Figure 2.

\section{Research procedure}

\section{Vegetation analysis}

Vegetation data collected were analyzed to obtain the value of Relative Density (RD), Relative Frequency (RF),
Relative Dominance (RD), and Important Value Index (IVI) on understorey.

\section{Measurement of biomass}

Sample of understorey biomass was carried out by the destructive method (taking plant parts as examples). The understorey taken as examples is all living plants $<5 \mathrm{~cm}$ in diameter, herbs, and grasses. Data collection of understorey in the field is done by harvesting all understorey in sample plots measuring $1 \mathrm{~m} \times 1 \mathrm{~m}$. All samples of the understorey were then weighed, so that the wet weight of each plot was known. The understorey weight wet is the sum of all the weight wet of all the understorey plots (Hairiah et al. 2011).

\section{Analysis in the laboratory}

Analysis in the laboratory includes water content, flying content, ash content, and carbon content. Procedure for determining levels of flying content using the American Society for Testing Materials (ASTM) D 5832-98. Procedure for determining ash content using the American Society for Testing Materials (ASTM) D 2866-94. Determination of carbon content of test samples using the Indonesian National Standard (SNI) 06-3730-1995. Measurement of test samples from each part of the understorey was carried out three replications.

\section{Data processing}

To test the significance of the difference in the average plant carbon stock in agroforestry land and rubber monoculture, it is necessary to do a t-test using SPSS software. The t-test used was the independent sample t-test.

The hypothesis of this study is that there are significant differences in the carbon stock of understorey in rubber agroforestry and rubber monoculture. Therefore, the decision making criteria are as follows: (i) If Sig (2-tailed) value > 0.05 , then $\mathrm{H} 0$ is accepted (not significantly different). (ii) If Sig (2-tailed) value $<0.05$, then $\mathrm{H} 0$ is rejected (significantly different).

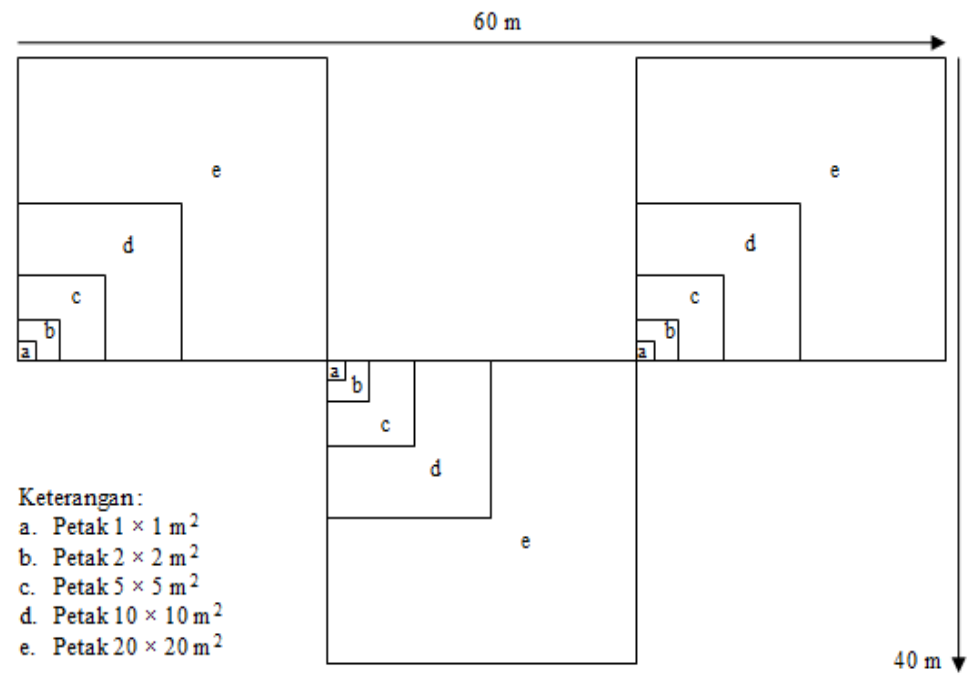

Figure 2. Design of sample plot 


\section{RESULTS AND DISCUSSION}

\section{Structure and composition of stands in rubber agroforestry}

The agroforestry system in the object of this study includes a simple agroforestry system, which is a land-use system that combines trees with one or more seasonal species. The condition of rubber agroforestry can be seen in Figure 3.A.

Based on CBS Central Tapanuli (2012), this agroforestry is dominated by 10-12 years old rubber plants and they are natural rubber plants. The area of this rubber agroforestry is 1.5 ha with a spacing of $3 \mathrm{~m} \times 3 \mathrm{~m}$. The composition of the types of agroforestry constituent plants can be seen in Table 1 .

The constituent composition of agroforestry consists of forestry plants and agricultural crops. Hevea brasiliensis, Archidendron pauciflorum, Mangifera odorata, Durio zibethinus, Artocarpus heterophyllus, Parkia speciosa, Nephelium lappaceum, Citrus aurantifolia, and Arenga pinnata are forestry plants. Manihot utilissima, Musa paradisiaca, Ananas comosus, and Alpinia galangal are agricultural crops. Importance value index (IVI) of this agroforestry land, in general, ranged from 10 to188. These values match with the range of 10 to 77 in a subtropical forest in north India (Singh et al. 2011). IVI is used to determine the overall importance of each species in the community structure. Species with the greatest importance value are the primary dominant species of specified vegetation (Simon and Girma 2004).

Based on the analysis of vegetation, it is obtained that the trees that dominate on agroforestry land are rubber trees with an IVI value of $188.44 \%$ and the lowest on durian, which is $10.57 \%$. IVI of a type is a value that describes the role of the existence of a type in a community. The greater the IVI of a type, the greater the role of that type in the community. The highest IVI value in rubber plants shows that the role of these types is very large in a community.
The tree-level importance index for rubber agroforestry can be seen in Table 2 .

The large value of IVI on rubber trees is caused by rubber plants being planted as the main crop in this agroforestry system. Rubber tree sap production is used by agroforestry landowners as a source of livelihood. Other plants such as Archidendron pauciflorum, Artocarpus heterophyllus, Parkia speciosa, Mangifera odorata, and Durio zibethinus were planted earlier in agroforestry land as crops for consumption. Idris et al. (2013) state a plant species can play a role if the IVI for tree levels is more than $15 \%$. From the analysis of tree-level vegetation, the types that play a role are Hevea brasiliensis, Archidendron pauciflorum, Artocarpus heterophyllus, and Parkia speciosa. In addition to modest biodiversity benefits, rubber agroforests could provide additional ecosystem functions and services. Integration of native trees into rubber improves water infiltration, improving and stabilizing soil (Langenberger et al. 2017), while reducing herbicide use, decreases runoff, soil erosion and loss of total organic soil carbon (Liu et al. 2016).

Table 1. Species composition in rubber agroforestry

\begin{tabular}{ll}
\hline Local name & Botanical name \\
\hline Karet & Hevea brasiliensis \\
Jengkol & Archidendron pauciflorum \\
Kuweni & Mangifera odorata \\
Durian & Durio zibethinus \\
Nangka & Artocarpus heterophyllus \\
Petai & Parkia speciosa \\
Rambutan & Nephelium lappaceum \\
Jeruk nipis & Citrus aurantifolia \\
Aren & Arenga pinnata \\
Singkong & Manihot utilissima \\
Pisang & Musa paradisiaca \\
Nanas & Ananas comosus \\
Lengkuas & Alpinia galangal \\
\hline
\end{tabular}
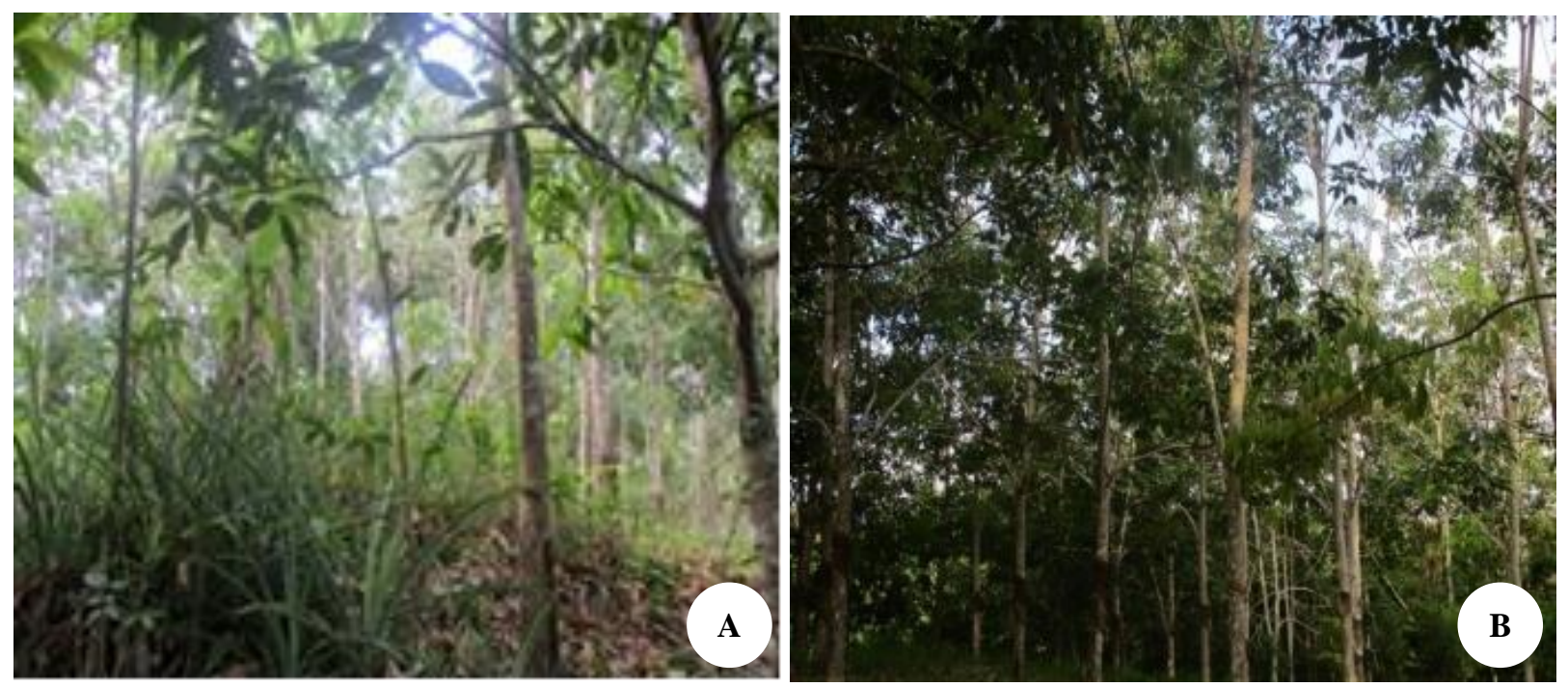

Figure 3. A. Rubber agroforestry, B. Rubber monoculture 
Table 2. Importance Value Index species composition in rubber agroforestry

\begin{tabular}{llccccccc}
\hline $\begin{array}{l}\text { Local } \\
\text { name }\end{array}$ & Botanical name & Density & $\begin{array}{c}\text { RD } \\
(\boldsymbol{\%})\end{array}$ & Frequency & $\begin{array}{c}\text { RF } \\
(\boldsymbol{\%})\end{array}$ & Dominance & RD (\%) & IVI (\%) \\
\hline Rubber & Hevea brasiliensis & 52.78 & 63.33 & 0.78 & 43.75 & 36.71 & 81.36 & 188.44 \\
Jengkol & Archidendron pauciflorum & 13.89 & 16.67 & 0.33 & 18.75 & 4.87 & 10.80 & 46.22 \\
Jackfruit & Artocarpus heterophyllus & 5.56 & 6.67 & 0.22 & 12.5 & 0.72 & 1.60 & 20.77 \\
Petai & Parkia speciosa & 5.56 & 6.67 & 0.22 & 12.5 & 0.58 & 1.29 & 20.46 \\
Kuweni & Mangifera odorata & 2.78 & 3.33 & 0.11 & 6.25 & 1.79 & 3.96 & 13.54 \\
Durian & Durio zibethinus & 2.78 & 3.33 & 0.11 & 6.25 & 0.45 & 0.99 & 10.57 \\
Total & & 83.35 & 100 & 1.77 & 100 & 45.12 & 100 & 300 \\
\hline
\end{tabular}

\section{Structure and composition of stands in rubber monoculture}

Types of rubber plants in this monoculture land are PB 260 rubber clones which are 8-12 years old. PB 260 clone was included in the latex producing clone which had been recommended by the Sembawa Research Center-Rubber Research Center for the period 2006-2010. PB 260 clone is one of the selected rubber clones for Sumatra and Kalimantan. Several types of clones that have been selected for rubber-based agroforestry systems including PB 260 provide good results, fast stem growth, and can adapt to the conditions of community plantations whose management conditions are not as good as large plantations (Joshi et al. 2001). The shape of the canopy and the condition of rubber monoculture can be seen in Figure 3.B.

The area of monoculture planted with rubber plants is around 1.5 ha with a spacing of $3 \mathrm{~m} \times 5 \mathrm{~m}$ and $3 \mathrm{~m} \times 6 \mathrm{~m}$. The results of tree-level vegetation analysis showed that the Hevea brasiliensis frequency of 0.56 with important value index is $300 \%$. Value of relative density and relative frequency is $100 \%$ and the dominance is 28.24 in rubber monoculture.

Based on the analysis of tree-level vegetation data obtained that the value of the density of rubber plants is 41.67 individuals/ha. This density value is smaller than the density of trees in agroforestry. This is caused by the spacing in agroforestry is closer than monoculture. According to Nissen et al. (2001), particularly planting density plays a vital role in the growth of trees and also influences the function and structure of the forest ecosystem. Furthermore, Wang (2015), the decreased tree growth with high planting density can be due to competition over growing resources such as light, water, and nutrients which in turn affects crown size, synthesis of carbohydrates and hormonal growth regulators (Dong et al. 2015) that finally can affect to biomass.

The value of the frequency of rubber trees in monocultures is 0.56 . This frequency value indicates that the spread of rubber plants at the tree level is not evenly distributed. This is likely due to differences in the time of planting rubber so that rubber which is planted earlier is only found in a few plots.

\section{Structure and composition of understorey plant in rubber agroforestry and monoculture}

Based on the results of an inventory of understorey plants in Sijungkang Village, Andam Dewi Sub-district,
Central Tapanuli District, North Sumatra Province, obtained 23 species of understorey plants in rubber agroforestry and 15 understorey plant types in rubber monoculture. In total, all species of understorey plant found at these two locations were 28 species. Understorey species in rubber agroforestry and monoculture can be seen in Table 3 and Table 4.

The number and species of understorey plant in rubber agroforestry is higher than that of rubber monoculture. This is caused by land management in the form of spraying weeds in monoculture more intensively than agroforestry. This is in accordance with the statement of Langi (2007) which states that the existence of understorey plant on land owned is very dynamic. This is due to the management carried out by farmers on several types of land which is quite intensive so that the presence of understorey plants is very dynamic. More intensive management in the rubber monoculture land causes the growth of understorey species to be lower. Besides, this may be due to the high number of species richness in rubber agroforestry compared to rubber monoculture. Misgana et al. (2010) said that the species richness also showed the variation between the two agroecological parkland agroforestry.

Correspondingly, agroforestry systems have been well recognized as an improvement on monocultures and being closer to native forests (Chaudhary et al. 2016). They can provide a wide variety of goods (e.g. rubber, coconut, coffee, or cacao), reduce poverty, increase carbon storage, enhance soil fertility and improve water and air quality (Jose 2009). Growing trees with agricultural crops can also produce high-value wood products and bioenergy, minimize the risk of pest outbreaks and enhance biodiversity (Nerlich et al. 2013).

Based on the results of the inventory there are ten species of understorey plant that are always found in these two locations, including Ramuk-Ramuk (Borreria latifolia), Sanggul Lote (Porophyllum ruderale), Rumput Teki (Cyperus rotundus), Rumput Setaria (Setaria sphacelata), Salhot Babi (Paspalum conjugatum), Belimbing Tanah (Oxalis barrelieri), Simarbau-bau (Cromolaena odorata), Rumput Keriting (Diodia sarmentosa), Kacang Asu (Calopogonium mucunoides), dan Simarriman-riman (Lygodium microphyllum). The similarity of understorey plant species found in the two locations was due to the species having a wide tolerance limit to light intensity and nutritional competition which were considered as very important factors in plant growth. 
The number of understorey plant species found only in agroforestry and rubber monoculture is 18 species. Species that are only found in a location show that these species have a narrow tolerance limit to light intensity so that differences in canopy cover in agroforestry and monoculture cause these species are only found in one location (Fitter and Hay 1991). The importance value index of understorey plants in rubber agroforestry and rubber monoculture can be seen in Table 5 and Table 6 .

Based on Table 5 and Table 6, the type of understorey plant that predominates in rubber agroforestry is Situdu Langit (Stachytarpheta jamaicensis) with an IVI of 30.64\% and in rubber, monoculture is Ara Sungsang (Asystasia gangetica) of $33.01 \%$. Indriyanto (2006) states that the dominant species (in power) in a plant community will have a high importance value index, so that the most dominant species certainly has the highest importance value index. Types of understorey plant that dominate in each location can be seen in Figure 4.

Understorey plant species that have the lowest IVI in rubber agroforestry are Paku Harupat (Nephrolepis bisserata), Andorpalas (Tetracera indica), Rumput Teki (Cyperus rotundus), Simarriman-riman (Lygodium microphyllum), and Sanduduk Bulu (Clidemia hirta) with IVI of $2.47 \%$, whereas in rubber monoculture were Kacang Asu (Calopogonium mucunoides) and Simarriman-riman (Lygodium microphyllum) with an IVI of $2.56 \%$. RD and RF values are also the lowest. This shows that the lowest vegetation was found in the sample plot and the lowest spread rate.
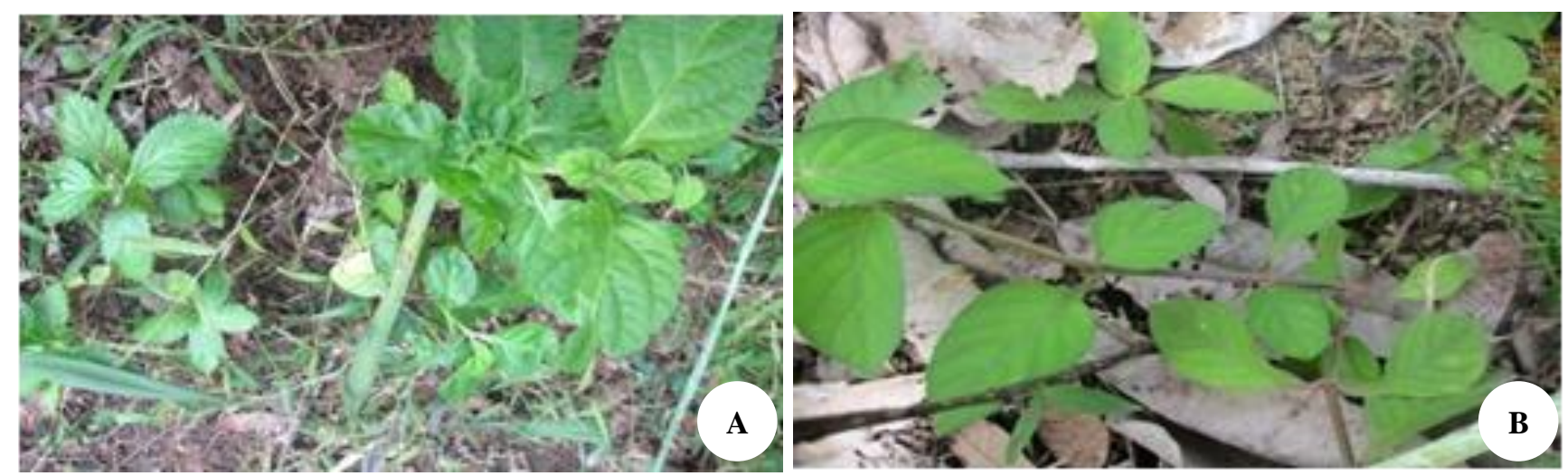

Figure 4. Types of understorey plants. A. Stachytarpheta jamaicensis, B. Asystasia gangetica

Table 3. Types of understorey in rubber agroforestry

\begin{tabular}{|c|c|c|}
\hline Local name & Botanical name & $\begin{array}{c}\text { Total } \\
\text { number }\end{array}$ \\
\hline Situdu langit & Stachytarpheta jamaicensis & 42 \\
\hline Bawang- bawangan & Eleutherine americana & 21 \\
\hline Rumput sabut & Ottochloa nodosa & 15 \\
\hline Salhot babi & Paspalum conjugatum & 15 \\
\hline Paku pita & Vittaria elongata & 14 \\
\hline Rumput tali & Desmodium triflorum & 13 \\
\hline Lalang & Imperata cylindrica & 13 \\
\hline Ria-ria & Scleria sumatrensis & 8 \\
\hline Rumput setaria & Setaria sphacelata & 6 \\
\hline Sanduduk & Melastoma malabathricum & 6 \\
\hline Simarbau-bau & Cromolaena odorata & 5 \\
\hline Rumput jenggot & Sporobolus indicus & 5 \\
\hline Belimbing tanah & Oxalis barrelieri & 4 \\
\hline Sanggul lote & Porophyllum ruderale & 3 \\
\hline Rumput keriting & Diodia sarmentosa & 2 \\
\hline Kacang asu & Calopogonium mucunoides & 2 \\
\hline Ramuk-ramuk & Borreria latifolia & 2 \\
\hline Nasi-nasi & Sauropus androgynus & 2 \\
\hline Pahu harupat & Nephrolepis bisserata & 1 \\
\hline Andorpalas & Tetracera indica & 1 \\
\hline Rumput teki & Cyperus rotundus & 1 \\
\hline Simarriman-riman & Lygodium microphyllum & 1 \\
\hline Sanduduk bulu & Clidemia hirta & 1 \\
\hline Total & & 183 \\
\hline
\end{tabular}

Table 4. Types of understorey in rubber monoculture

\begin{tabular}{llc}
\hline Local name & Botanical name & $\begin{array}{c}\text { Total } \\
\text { number }\end{array}$ \\
\hline Ara sungsang & Asystasia gangetica & 32 \\
Ramuk-ramuk & Borreria latifolia & 26 \\
Rumput rotan & Echinochloa colona & 22 \\
Sanggul lote & Porophyllum ruderale & 20 \\
Rumput teki & Cyperus rotundus & 14 \\
Akar wangi & Polygala paniculata & 13 \\
Rumput setaria & Setaria sphacelata & 9 \\
Salhot babi & Paspalum conjugatum & 8 \\
Sentro & Centrosema pubescens & 6 \\
Belimbing tanah & Oxalis barrelieri & 4 \\
Simarbau-bau & Cromolaena odorata & 4 \\
Sitanggis & Belamcanda chinensis & 3 \\
Rumput keriting & Diodia sarmentosa & 3 \\
Kacang asu & Calopogonium mucunoides & 1 \\
Simarriman-riman & Lygodium microphyllum & 1 \\
Total & & 166 \\
\hline
\end{tabular}


Table 5. Importance Value Index of understorey in rubber agroforestry

\begin{tabular}{|c|c|c|c|c|c|c|}
\hline Local name & Botanical name & Density & $\mathbf{R D}(\%)$ & Frequency & RF (\%) & IVI $(\%)$ \\
\hline Situdu langit & Stachytarpheta jamaicensis & 46666.67 & 22.95 & 0.44 & 7.69 & 30.64 \\
\hline Bawang-bawangan & Eleutherine americana & 23333.33 & 11.48 & 0.44 & 7.69 & 19.17 \\
\hline Rumput sabut & Ottochloa nodosa & 16666.67 & 8.20 & 0.56 & 9.62 & 17.82 \\
\hline Rumput tali & Desmodium triflorum & 14444.44 & 7.10 & 0.44 & 7.69 & 14.79 \\
\hline Lalang & Imperata cylindrica & 14444.44 & 7.10 & 0.44 & 7.69 & 14.79 \\
\hline Salhot babi & Paspalum conjugatum & 16666.67 & 8.20 & 0.33 & 5.77 & 13.97 \\
\hline Ria-ria & Scleria sumatrensis & 8888.89 & 4.37 & 0.44 & 7.69 & 12.06 \\
\hline Paku pita & Vittaria elongata & 15555.56 & 7.65 & 0.22 & 3.85 & 11.50 \\
\hline Sanduduk & Melastoma malabathricum & 6666.67 & 3.28 & 0.33 & 5.77 & 9.05 \\
\hline Rumput setaria & Setaria sphacelata & 6666.67 & 3.28 & 0.22 & 3.85 & 7.13 \\
\hline Simarbau-bau & Cromolaena odorata & 5555.56 & 2.73 & 0.22 & 3.85 & 6.58 \\
\hline Sanggul lote & Porophyllum ruderale & 3333.33 & 1.64 & 0.22 & 3.85 & 5.49 \\
\hline Rumput keriting & Diodia sarmentosa & 2222.22 & 1.09 & 0.22 & 3.85 & 4.94 \\
\hline Ramuk-ramuk & Borreria latifolia & 2222.22 & 1.09 & 0.22 & 3.85 & 4.94 \\
\hline Rumput jenggot & Sporobolus indicus & 5555.56 & 2.73 & 0.11 & 1.92 & 4.65 \\
\hline Belimbing tanah & Oxalis barrelieri & 4444.44 & 2.19 & 0.11 & 1.92 & 4.11 \\
\hline Kacang asu & Calopogonium mисunoides & 2222.22 & 1.09 & 0.11 & 1.92 & 3.01 \\
\hline Nasi-nasi & Sauropus androgynus & 2222.22 & 1.09 & 0.11 & 1.92 & 3.01 \\
\hline Pahu harupat & Nephrolepis bisserata & 1111.11 & 0.55 & 0.11 & 1.92 & 2.47 \\
\hline Andorpalas & Tetracera indica & 1111.11 & 0.55 & 0.11 & 1.92 & 2.47 \\
\hline Rumput teki & Cyperus rotundus & 1111.11 & 0.55 & 0.11 & 1.92 & 2.47 \\
\hline Simarriman-riman & Lygodium microphyllum & 1111.11 & 0.55 & 0.11 & 1.92 & 2.47 \\
\hline Sanduduk bulu & Clidemia hirta & 1111.11 & 0.55 & 0.11 & 1.92 & 2.47 \\
\hline Total & & 203333.3 & 100 & 5.78 & 100 & 200 \\
\hline
\end{tabular}

Table 6. Importance Value Index of understorey in rubber monoculture

\begin{tabular}{|c|c|c|c|c|c|c|}
\hline Local name & Botanical name & Density & RD $(\%)$ & Frequency & RF (\%) & IVI (\%) \\
\hline Ara sungsang & Asystasia gangetica & 35555.56 & 19.28 & 0.78 & 13.73 & 33.01 \\
\hline Ramuk-ramuk & Borreria latifolia & 28888.89 & 15.66 & 0.67 & 11.76 & 27.42 \\
\hline Rumput rotan & Echinochloa colona & 24444.44 & 13.25 & 0.44 & 7.84 & 21.09 \\
\hline Sanggul lote & Porophyllum ruderale & 22222.22 & 12.05 & 0.44 & 7.84 & 19.89 \\
\hline Rumput teki & Cyperus rotundus & 15555.56 & 8.43 & 0.56 & 9.80 & 18.23 \\
\hline Salhot babi & Paspalum conjugatum & 8888.89 & 4.82 & 0.56 & 9.80 & 14.62 \\
\hline Akar wangi & Polygala paniculata & 14444.44 & 7.83 & 0.33 & 5.88 & 13.71 \\
\hline Rumput setaria & Setaria sphacelata & 10000.00 & 5.42 & 0.44 & 7.84 & 13.26 \\
\hline Belimbing tanah & Oxalis barrelieri & 4444.44 & 2.41 & 0.33 & 5.88 & 8.29 \\
\hline Rumput keriting & Diodia sarmentosa & 3333.33 & 1.81 & 0.33 & 5.88 & 7.69 \\
\hline Sentro & Centrosema pubescens & 6666.67 & 3.61 & 0.22 & 3.92 & 7.53 \\
\hline Simarbau-bau & Cromolaena odorata & 4444.44 & 2.41 & 0.22 & 3.92 & 6.33 \\
\hline Sitanggis & Belamcanda chinensis & 3333.33 & 1.81 & 0.11 & 1.96 & 3.77 \\
\hline Kacang asu & Calopogonium mисunoides & 1111.11 & 0.60 & 0.11 & 1.96 & 2.56 \\
\hline Simarriman-riman & Lygodium microphyllum & 1111.11 & 0.60 & 0.11 & 1.96 & 2.56 \\
\hline Total & & 184444.4 & 100 & 5.67 & 100 & 200 \\
\hline
\end{tabular}

In most of these studies, forest control usually presents a much higher diversity, especially because it is supposed to be more complex in terms of botanical composition and vegetation structure. Deheuvels et al. (2014) found that cocoa-based agroforests in Talamanca were significantly less diverse than neighboring forest patches. Besides, forest patches do not only have a higher number of terrestrial plant species than cocoa agroforests, but plant species composition in nearby forest patches differs strongly from cocoa agroforests.

\section{Diversity index and uniformity index}

Based on observations obtained the diversity index $\left(\mathrm{H}^{\prime}\right)$ of understorey plant in rubber agroforestry was 2.62 and in rubber monoculture was 2.35 . Index of understorey plant diversity in rubber agroforestry is higher than monoculture due to the number of understorey plant species found more in rubber agroforestry. This is consistent with the statement of Indriyanto (2006) which states that the diversity of species of a community is high if the community is composed of many types. Conversely, a community is said 
to have low species diversity if the community is composed of a few types and only a few dominant species (Wasof et al. 2018). Furthermore Loreau and Hector (2001), diversity can also increase productivity through selection effects, where communities that contain a larger sample of the species pool are more likely to contain high functioning species that contribute strongly to ecosystem productivity.

The index value of understorey plant diversity obtained at these two locations is in the medium category. Mason (1980) states that if the diversity index value is less than 1, it means that species diversity is low, if between 1-3 means moderate species diversity, if greater than 3 means high species diversity. Index of understorey diversity which is classified as moderate at these two locations shows that environmental factors affect the diversity of plant species that can grow in environmental conditions such as Sijungkang Village. According to Sofiah et al. (2013), the composition and diversity of plant species in an area depend on several environmental factors, such as humidity, nutrients and minerals, sunlight, topography, host rock, soil characteristics, canopy structure and historical land use.

Uniformity Index (E) of understorey plant in rubber agroforestry is 0.83 and in rubber monoculture is 0.87 . This value indicates that the uniformity of understorey plants in both locations is relatively high. This means that different types of understorey plants in both locations are classified as few. Krebs (1985) states that the Uniformity Index is low when $0<\mathrm{E}<0.5$ and uniformity is high if $0.5<\mathrm{E}<1$.

\section{Water content}

Based on the results of laboratory analysis, the average water content of understorey plants in rubber agroforestry was $204.23 \%$ and in rubber monoculture was $332.42 \%$. The results of the analysis showed that the largest average water content was found in the understorey plant in rubber monoculture. The difference in water content in the two locations is caused by the types of understorey plants at the two locations also differ so that the difference in water content in each understorey plant affects the average value of the water content at each location. Recapitulation of understorey water content in rubber agroforestry and rubber monoculture can be seen in Table 7 .

The percentage of water content obtained in each plot shows a value higher than 100. Hani (2012) states that the water content of material shows the amount of water content of the unity of the weight of the material which can be expressed in percent of wet weight (wet basis) or in percent dry weight (dry basis). Wet weight water content has a theoretical maximum limit of $100 \%$, while the dry weight water content can be more than $100 \%$. The results of the calculation of the water content showed that the water content of the understorey plant in rubber agroforestry and rubber monoculture \pm 3.6 times the dry weight.

The water content in rubber monoculture is greater than rubber agroforestry caused by interspecific competition for water between rubber trees and the other plant in agroforestry systems. According to $\mathrm{Wu}$ et al. (2016), to avoid intense competition with the interplanted species for water, rubber trees expanded their water absorption zone to the deep soil layer. This response not only satisfied the demand for water by rubber trees, but also avoided excessive intraspecific competition and expanded the nutrient absorption zone to facilitate nutrient uptake by rubber trees. In addition, there was no evidence that this inevitable competition had a negative effect on rubber trees. In contrast, the competition greatly improved the WUE of rubber trees to reduce excessive water use; this is beneficial for water conservation in the rainy season, and ensures a normal water demand for plant growth under water shortages in the dry season.

\section{Understorey plant biomass}

Average understorey plant biomass in rubber agroforestry and rubber monoculture was 0.89 tons/ha. The average understorey plant biomass in rubber monoculture $(0.94 \mathrm{ton} / \mathrm{ha})$ is greater than in rubber agroforestry $(0.84$ ton/ha). Although the number of understorey plant species in rubber agroforestry is greater than that of rubber monoculture, this species diversity does not affect the amount of biomass. Sullivan et al. (2017), indicating that diversity is not a correlate of the key structural factors that lead to high biomass in some tropical forest stands. Recapitulation of understorey plant biomass in rubber agroforestry and rubber monoculture can be seen in Table 8 .

The average of understorey plant biomass in rubber monoculture is greater than in agroforestry due to the lower stand density in monoculture so that the canopy in monoculture land is more open. This canopy transparency causes sunlight to reach the lower vegetation. Azham (2015) states that the closer the canopy of trees making up a land, the understorey plant biomass will decrease due to lack of sunlight reaching the forest floor, causing the growth of under vegetation to be depressed and unable to grow. Furthermore, interspecific competition for light, moisture, and nutrients between planted seedlings and surrounding vegetation are believed to be a principal factor affecting the growth and survival of planted seedlings in plantations (Zhang et al. 2008).

At plantation stand level, biomass production increases with increasing stand density due to the biomass of the extra trees compensating for the decrease in the size of individuals (Dickens et al. 2004). The result of study Farooq et al. (2019) that larger biomass of needles, bark, stem, stump root, and coarse roots was recorded for trees in intermediate-density stand than either the low or highdensity stand. The above-ground biomass was the largest in intermediate-density stand followed by the low-density stand and the smallest being in high-density stand.

\section{Understorey plant carbon}

Average of understorey plant carbon stock in rubber agroforestry and rubber monoculture was 0.23 tons/ha. The average of the plant carbon stock in rubber monoculture $(0.25$ tons/ha) is greater than in rubber agroforestry $(0.21$ tons/ha). This is caused by the average understorey plant biomass in the rubber monoculture is higher than rubber agroforestry. According to Ariani et al. (2014), the amount of stored carbon is closely related to biomass storage. The ability of vegetation to store biomass directly can describe 
the condition of carbon storage in a forest area. This is because carbon is a fraction of $\mathrm{CO}_{2}$ absorbed by green vegetation which is then broken down into biomass and stored in the form of carbon. The quantity of carbon deposits is directly proportional to the quantity of biomass deposits. Recapitulation of understorey plant carbon in rubber agroforestry and rubber monoculture can be seen in Table 9.

Table 8 and Table 9 show that the average value of understorey plant biomass in rubber monoculture is also followed by the average value of carbon stock in rubber monoculture. Based on these data, where is the stand density that affects the understorey biomass will also affect the understorey carbon stock. Chanan (2012) states that carbon storage is strongly influenced by biomass. Therefore Latifah et al. (2018) state that indigenous agroforestry technique is effective technique to increase carbon stocks.

The number of understorey species in rubber monoculture is lower than agroforestry, but the carbon stock of understorey in rubber monoculture is greater. This is due to the intensity of light obtained by the understorey plants in rubber monoculture is higher than rubber agroforestry. C storage of land becomes greater if the soil fertility is good, or in other words, the amount of $\mathrm{C}$ stored above the ground (plant biomass) is determined by the amount of C stored in the soil (Chefetz 2007). Rusolono (2006) shows the average of plant carbon in agroforestry in Pecekelan Village, Central Java, and Kertayasa Village, West Java is 0.3 tons/ha and 0.2 tons/ha. Siarudin et al. (2014) in the Balantieng watershed, South Sulawesi show that the carbon stock of understorey in mixed gardens is 0.002 tons/ha and in rubber monoculture is 0.006 tons/ha.

Our results are different from those of Santhyami et al. (2018), where total aboveground C-stock in biomass was six to ten times higher in the cacao-based agroforestry than in monoculture cacao. This difference is due to differences in undergrowth species in monoculture and agroforestry systems. Agroforestry systems are thus recognized to have the potential to regain some of the carbon lost to the atmosphere in the clearing of primary or secondary forests. Although neither it can come close to replacing the full amount of carbon that was present in the primary forest, agroforestry systems have the added benefit of providing valuable products and food to local people. To estimate how met or agroforestry capacity is in storing carbon, it is necessary to compare it with natural forests.

Several studies have assessed the carbon stock of natural forests, Simorangkir (2016) in the arboretum and Pondok Buluh Training Forest with an average carbon stock of 4.095 tons/ha. When compared with carbon stocks found in forests, the carbon research in agroforestry and rubber monoculture in Sijungkang Village is smaller $(0.23$ ton/ha). Based on the results of the study of carbon stocks obtained data that the carbon stock of understorey in agroforestry and monocultures on community land is smaller than the carbon stock of understorey contained in the forest. According to Wang et al. (2016), many factors can affect the forest ecosystem carbon and nitrogen stocks by affecting the carbon and nitrogen processes between plants and soil in the forest ecosystem. Furthermore, Weifeng et al. (2011) said that the structure and composition of vegetation (tree species, density, etc.) affect the aboveground biomass carbon. Some researchers indicated that differences of carbon stocks in plant stands depend on part of plant (Muhdi et al. 2019) and improved forest management can diminish $\mathrm{CO}_{2}$ emissions Putz et al. (2008) and stand damages (Purwoko et al. 2018).

The understorey vegetation (shrub and herb layers) is also an important part of the forest ecosystem and plays an important role in nutrient turn-over and cycling (Creamer et al. 2015; Manuel et al. 2015). Different understorey vegetation with different carbon and nitrogen stocks can alter the soil microbes (Sun et al. 2017), soil properties and structure (Mihoc et al. 2016) and soil temperature and water content (Gurlevik et al. 2004) which may ultimately have a great influence on soil carbon and nitrogen (Pan et al. 2018).

Table 7. Recapitulation of understorey water content in rubber agroforestry and rubber monoculture

\begin{tabular}{ccc}
\hline No. Plot & $\begin{array}{c}\text { Water content in } \\
\text { rubber agroforestry } \\
(\boldsymbol{\%})\end{array}$ & $\begin{array}{c}\text { Water content in } \\
\text { rubber monoculture } \\
(\boldsymbol{\%})\end{array}$ \\
\hline I & 203.06 & 273.46 \\
II & 236.10 & 321.19 \\
III & 173.54 & 402.61 \\
Means & 204.23 & 332.42 \\
\hline
\end{tabular}

Table 8. Recapitulation of understorey biomass in rubber agroforestry and rubber monoculture

\begin{tabular}{llc}
\hline \multicolumn{1}{c}{ Area } & Plot & $\begin{array}{c}\text { Biomass } \\
\text { (ton/ha) }\end{array}$ \\
\hline Rubber agroforestry & I & 1.32 \\
& II & 0.89 \\
& III & 0.32 \\
& Means & 0.84 \\
Rubber monoculture & I & \\
& II & 0.71 \\
& III & 1.77 \\
Means & Means & 0.34 \\
& & 0.94 \\
\hline
\end{tabular}

Table 9. Recapitulation of understorey carbon in rubber agroforestry and rubber monoculture

\begin{tabular}{llc}
\multicolumn{1}{c}{ Area } & Plot & $\begin{array}{c}\text { Carbon } \\
\text { (ton/ha) }\end{array}$ \\
\hline Rubber agroforestry & I & 0.31 \\
& II & 0.23 \\
& III & 0.07 \\
& Means & 0.21 \\
Rubber monoculture & I & \\
& II & 0.18 \\
& III & 0.43 \\
Means & Means & 0.08 \\
& & 0.25 \\
\end{tabular}


Table 10. Recapitulation of independent sample t-test for understorey on rubber agroforestry and rubber monoculture

\begin{tabular}{lcc}
\hline Area & Carbon average & $\begin{array}{c}\text { Average carbon } \\
\text { difference }\end{array}$ \\
\hline Rubber agroforestry & 0.21 & 0.04 \\
Rubber monoculture & 0.25 & 04 \\
\hline
\end{tabular}

\section{Independent sample t-test}

Recapitulation of independent sample t-test of understorey carbon on rubber agroforestry and rubber monoculture can be seen in Table 10.

Based on the results of the independent sample t-test at a 95\% confidence interval, data were obtained that the carbon stock of the understorey plants in rubber agroforestry and rubber monoculture was not significantly different (hypothesis rejected). This is caused by land management factors in rubber agroforestry and rubber monoculture. Land management such as weed spraying in rubber monoculture is more intensive, but the density of the rubber stands to make up the monoculture land is lower compared to rubber agroforestry. This causes the vegetation to grow faster because of the openness of the canopy. Differences in land management such as weed spraying and differences in the density of the compilers of the rubber agroforestry and rubber monoculture stands cause the number of individuals and the size of understorey plants in the two areas was not different, so that the carbon stocks were also not significantly different. Some previous studies that show significant differences in carbon and nitrogen stocks among different forest ecosystems, and the differences were mostly attributed to the differences in compositions of tree species (Hansson et al. 2013; He et al 2013; Yang et al. 2014). This result indicates the importance of understory vegetation as a characteristic classification symbol of forest in the estimation of forest ecosystem carbon.

\section{ACKNOWLEDGEMENTS}

Thanks to the Rector of the Universitas Sumatera Utara, Indonesia for funding this research through BPPTN scheme in 2016. The author also thanks the people of Sijungkang Village, Andam Dewi Sub-district, Central Tapanuli District, North Sumatra for assisting researchers during fieldwork.

\section{REFERENCES}

American Society for Testing Material. 2004. ASTM D 2866-94. Standard Test Method for Total Ash Content of Activated Carbon. ASTM International, United States of America.

Ariani A, Sudhartono, Wahid A. 2014. Biomass and carbon of understorey around Tambing Lake in the Lore Lindu National Park area. Warta Rimba 2 (1): 164-170.

Atanga A, Khasa D, Chang S, Degrande A. 2013. Carbon sequestration in agroforestry systems. Tropical Agroforestry. Springer, Dordrecht. DOI: 10.1007/978-94-007-7723-1_10.

Aththorick TA. 2005. Similarity of understorey communities in several types of plantation ecosystems in Labuhan Batu District. Komunikas Penelitian 17 (5): 42-48.
Azham Z. 2015. Estimated carbon stocks in secondary forest cover, bush and shrub in Samarinda. Agrifor 14 (2): 325-338.

Azhar I, Risnasari I, Muhdi, Srena MF, Riswan. 2019. The utilization of sugar palm (Arenga pinnata) by the people around Batang Gadis Nasional Park Area. IOP Conf. Ser.: Earth Environ Sci 305: 012016. DOI: $10.1088 / 1755-1315 / 305 / 1 / 012016$.

Chanan M. 2012. Estimating carbon stock (c) stored above ground level in teak forest vegetation (Tectona grandis Linn. F) (in RPH Sengguruh BKPH Sengguruh KPH Malang Perum Perhutani II East Java). Gamma 7 (2): 61-73. [Indonesian]

Chazdon RL. 1998. Sunflecks and their importance to forest understorey plants. Adv Ecol Res 18: 1-63. DOI: 10.1016/S0065-2504(08)60179-8.

Chaudhary A, Burivalova Z, Koh LP, Hellweg S. 2016. Impact of forest management on species richness: global meta-analysis and economic trade-offs. Sci Rep 6: 23954. DOI: 10.1038/srep23954.

Chefetz B. 2007. Decomposition and sorption characterization of plant cuticles in soil. Plant Soil 298 (1): 21-30. DOI: 10.1007/s11104-0079318-1

Chelli S, Simonetti E, Wellstein C, Campetella G, Carnicelli S, Andreetta A, Giorgini D, Puletti N, Bartha S, Canullo R. 2019. Effects of climate, soil, forest structure and land use on the functional composition of the understorey in Italian forests. J Veg Sci 30 (6): 1110-1121.

Creamer CA, Menezes ABD, Krull ES, Sanderman J, Newton-Walters R, Farrell M. 2015. Microbial community structure mediates response of soil $\mathrm{C}$ decomposition to litter addition and warming. Soil Biol Biochem 80: 175-188. DOI: 10.1016/j.soilbio.2014.10.008.

Deheuvels O, Rousseau GX, Quiroga GS, Franco MD, Cerda R, Jose S, Mendoza V, Somarriba E. 2014. Biodiversity is affected by changes in management intensity of cocoa-based agroforests. Agrofor Syst 88: 1081-1099. DOI: 10.1007/s10457-014-9710-9.

Dendang B, Handayani W. 2015. Structure and composition of forest stands in Gunung Gede Pangrango National Park, West Java. Pros Sem Nas Masy Biodiv Indon 1 (4): 696-701.

Dickens ED, Barnett JP, Hubbard WG, Jokela EJ. 2004. Slash pine: still growing and growing! Proceedings of the slash pine symposium. Gen. Tech. Rep. SRS-76. U.S. Department of Agriculture, Forest Service, Southern Research Station, Asheville, NC.

Dong T, Zhang Y, Zhang Y, Zhang S. 2015. Continuous planting under a high density enhances the competition for nutrients among young Cunninghamia lanceolata saplings. Ann For Sci 73: 331-339. DOI: 10.1007/s13595-015-0518-1

Farooq TS, Wu W, Tigabu M, Ma X, He Z, Haroon M, Rashid, Gilani MM, Wu P. 2019. Growth, biomass production and root development of Chinese fir in relation to initial planting density. Forests 10: 236. DOI: $10.3390 / \mathrm{f} 10030236$.

Gurlevik N, Kelting DL, Allen HL. 2004. Nitrogen mineralization following vegetation control and fertilization in a 14-year-old loblolly pine plantation. Soil Sci Soc Am J 68: 272-281. DOI: 10.2136/sssaj2004.2720.

Hairiah K, Ekadinata A, Sari RR, Rahayu S. 2011. Measurement of Carbon Reserves: From Land Level to Landscape. Practical guide. Second edition. World Agroforestry Center, Bogor.

Hansson K, Fröberg M, Helmisaari HS, Kleja DB, Olsson BA, Olsson M, Persson T. 2013. Carbon and nitrogen pools and fluxes above and below ground in spruce, pine and birch stands in southern Sweden. For Ecol Manag 309: 28-35. DOI: 10.1016/j.foreco.2013.05.029.

Houghton RA. 2013. The emissions of carbon from deforestation and degradation in the tropics: past trends and future potential. Carbon Manag 4 (5): 539-546, DOI: $10.4155 / \mathrm{cmt} .13 .41$

He YK, Qin L, Li ZY, Liang XY, Shao MX, Tan L. 2013. Carbon storage capacity of monoculture and mixed-species plantations in subtropical China. For Ecol Manag 295: 193-198. DOI: 10.1016/j.foreco.2013.01.020.

Hilwan I, Mulyana D, Pananjung WG. 2013. The diversity of understorey on sengon buto stands (Enterolobium cyclocarpum Griseb.) and trembesi (Samanea saman Merr.) In the Post-mining Coal of PT Kitadin, Embalut, Kutai Kartanagara, East Kalimantan. Silvikultur Tropika 4 (1): 6-10.

Idris MH, Latifah S, Aji IML, Wahyuningsih E, Indriyatno, Ningsih RV. 2013. Study of vegetation and carbon stocks in Forest Areas with Special Purpose (KHDTK) Senaru, Bayan North Lombok. Ilmu Kehutanan 7 (1):25-36.

Jose S. 2009. Agroforestry for ecosystem services and environmental benefits: an overview. Agrofor Syst 76 (1): 1-10. DOI: 10.1007/s10457-009-9229-7. 
Krebs CJ. 1985. Ecology: the Experimental Analysis of Distribution and Abundance. 3rd ed. Harper \& Row, Publishers, Inc. New York.

Langenberger G, Cadisch G, Martin K, Min S, Waibel H. 2016. Rubber intercropping: A viable concept for the 21st century?. Agrofor Syst 91 (3): 577-596. DOI: 10.1007/s10457-016-9961-8.

Latifah S, Muhdi, Purwoko A, Tanjung E. 2018. Estimation of aboveground tree biomass Toona sureni and Coffea arabica in agroforestry system of Simalungun, North Sumatra, Indonesia. Biodiversitas 19 (2): 590-595 DOI: 10.13057/biodiv/d190239.

Liu H, Blagodatsky S, Giese M, Liu F, Xu J, Cadisch G. 2016. Impact of herbicide application on soil erosion and induced carbon loss in a rubber plantation of Southwest China. Catena 145: 180-192. DOI: 10.1016/j.catena.2016.06.007.

Loreau M, Hector A. 2001. Partitioning selection and complementarity in biodiversity experiments. Nature 412: 72-76. DOI: 10.1038/35083573.

Manuel DB, Pablo GP, Milla R, Gallardo A, Maestre FT. 2015. Soil characteristics determine soil carbon and nitrogen availability during leaf litter decomposition regardless of litter quality. Soil Biol Biochem 81: 134-142.

Mason CF. 1980. Ecology. 2nd ed. Longman Inc. New York.

Maxwell SL, Evans T, Watson JEM, Morel A, Grantham H, Duncan A, Harris N, Potapov P, Runting RK, Venter O, Wang S, Malhi Y. 2019. Degradation and forgone removals increase the carbon impact of intact forest loss by $626 \%$. Science Advances 5 (10): eaax2546. DOI: $10.1126 /$ sciadv.aax2546

Mihoc MAK, Giménez-Benavides L, Pescador DS, Sánchez AM, Cavieres LA, Escudero A. 2016. Soil under nurse plants is always better than outside: A survey on soil amelioration by a complete guild of nurse plants across a long environmental gradient. Plant Soil 408: 31-41. DOI: 10.1007/s11104-016-2908-z.

Misgana D, Shibru S, Chauhan R. 2020. Woody species diversity, structure and biomass carbon of parkland agroforestry practices in Gindeberet District, West Shoa Zone, Oromia Regional State, Ethiopia. Intl J Biodiv Conserv 12 (1): 1-14. DOI: 10.5897/IJBC2019.1335.

Muhdi, Sahar A, Hanafiah DS, Zaitunah A, Nababan FWB. 2019. Analysis of biomass and carbon potential on eucalyptus stands in industrial plantation forest, North Sumatra, Indonesia. 2019 IOP Conf Ser: Earth Environ Sci 374 012054. DOI: 10.1088/17551315/374/1/012054.

Nerlich K, Graeff-Hönninger S, Claupein W. 2013. Agroforestry in Europe: a review of the disappearance of traditional systems and development of modern agroforestry practices, with emphasis on experiences in Germany. Agrofor Syst 87 (2): 475-492. DOI: 10.1007/s10457-012-9560-2.

Nissen T, Midmore D, Keeler A. 2001. Biophysical and economic tradeoffs of intercropping timber with food crops in the Philippine uplands. Agric Syst (6): 49-69.

Pala NA, Gokhale Y, Shukla G, Chakravarty S. 2020. Potential of Homestead Gardens to gain from global carbon markets to mitigate climate change in Cooch Behar, West Bengal. Indian Forester, 146 (2): 159-164. DOI: 10.36808/if/2020/v146i2/130845.

Pan P, Zhao F, Ning JK, Zhang L, Ouyang XZ, Zang H. 2018. Impact of understory vegetation on soil carbon and nitrogen dynamic in aerially seeded Pinus massoniana plantations. PLoS ONE 13, e0191952. DOI: 10.1371/journal.pone.0191952.

Puwoko A, Muhdi, Hanafiah AS. 2018. Residual Stand Damages Caused by Conventional and Reduced Impact Timber Harvesting in the Natural Forest, Intl J Mechanic Eng Technol 9 (3): 313-325.

Putz FE, Sist P, Fredericksen T, Dykstra D. 2008. Reduced impact timber harvesting: challenges and opportunities. For Ecol Manag 256: 1427 1433. DOI: $10.1016 /$ j.foreco.2008.03.036.

Pye-Smith C. 2013. Rubber Agroforestry: Really rich rewards for environmental services? In: Tarman AE, Janudianto, Rahayu S (eds). Trees for Change no.08. World Agroforestry Center (ICRAF), Nairobi, Kenya.

Rijal S. 2019. Agroforestry System: Approaches for Climate Change Mitigation and Adaptation. Big Data In Agriculture (BDA) 1 (2): $23-$ 25. DOI: $10.26480 /$ bda.02.2019.23.25.

Rusolono T. 2006. Models for Estimating Agroforestry Standing Carbon Stocks for Management of Privately-Owned Forests Through Carbon Trading Schemes. [Dissertation]. IPB University, Bogor. [Indonesian]

Santhyami, Basukriadi A, Patria MP, Abdulhadi R. 2018. The comparison of aboveground C-stock between cacao-based agroforestry system and cacao monoculture practice in West Sumatra, Indonesia. Biodiversitas 19 (2): 472-479. DOI: 10.13057/biodiv/d190214.
Sayurandi, Suhendry I, Pasaribu SA. 2014. Testing the adaptation of some rubber clones during the immature plantations. Penelitian Karet 32 (1): $1-9$.

Sejati K. 2011. Global Warming, Food, and Water: Problems, Solutions, and Changes in the World Geopolitical Constellation. Gadjah Mada University Press. Yogyakarta.

Sekarini DA. 2010. Study of species diversity and carbon content of understorey plants in pine trees (Pinus merkusii Jungh. Et De Vriese) and teak (Tectona grandis L.F) at KPH Malang, Perum Perhutani Unit II East Java. IPB University. Bogor.

Siarudin M, Junaidi E, Widiyanto A, Indrajaya Y, Khasanah N, Tanika L, Lusiana B, Roshetko JM. 2014. Quantification of water environmental service and carbon of agroforestry patterns in community forests in the Jeneberang river area. Working paper 184. World Agroforestry Center, Bogor.

Simon SH, Girma B. 2004. Composition, structure \& regeneration status of woody species in Dindin natural forest, southeast Ethiopia: an implication for conservation. Ethiopian J Biol Sci 3 (1): 15-35

Simorangkir NH. 2016. Pendugaan cadangan karbon pada tumbuhan bawah di Hutan Diklat Pondok Buluh Kabupaten Simalungun. University of Sumatera Utara, Medan. [Indonesia]

Singh B, Tripathi KP, Singh K. 2011. Community structure, diversity, biomass and net production in a rehabilitated subtropical forest in North India. J For 1 (2): 11-26. DOI: 10.4236/ojf.2011.12003.

SNI [Standar Nasional Indonesia]. 1995. Arang Aktif Teknis (SNI 063730-1995). Badan Standardisasi Nasional Indonesia. Jakarta. [Indonesia]

Sofiah S, Setiadi D, Widyatmoko D. 2013. Distribution patterns, abundance and association of bamboo in plant communities in Gunung Baung Nature Park in East Java. Berita Biologi 12 (2): 239224.

Sullivan MJP, Talbot J, Lewis SL, Phillips OL, Qie L, Begne SK. 2017. Diversity and carbon storage across the tropical forest biome. Sci Rep 7: 39102. DOI: 10.1038/srep39102.

Sun YF, Zhang YQ, Feng W, Qin SG, Liu Z, Bai YX, Yan R, Fa KY. 2017. Effects of xeric shrubs on soil microbial communities in a desert in northern China. Plant Soil 414: 281-294. DOI. 10.1007/s11104-016-3111.

Wang C. 2015. Effect of planting density on knot attributes and branch occlusion of Betula alnoides under natural pruning in southern China. Forests 6: 1343-1361. DOI: 10.3390/f6041343.

Wang T, Kang FF, Cheng XQ, Han HR, Ji WJ. 2016. Soil organic carbon and total nitrogen stocks under different land uses in a hilly ecological restoration area of North China. Soil Tillage Res 163: 176-184. DOI: 10.1016/j.still.2016.05.015.

Wasof S, Lenoir J, Hattab T, Jamoneau A, Gallet-Moron E, Ampoorter E, Saguez R, Bennsadek L, Bertrand R, Valdès A, Verheyen K, Decocq G. 2018. Dominance of individual plant species is more important than diversity in explaining plant biomass in the forest understory. $\mathrm{J}$ Veg Sci 29 (3): 521-531. DOI:10.1111/jvs.12624.

Widyasari NAE, Saharjo BH, Solichin, Istomo. 2010. Estimation of biomass and carbon potential bound above the surface of the land in peat swamp forest in South Sumatra. Jurnal Ilmu Pertanian Indonesia 15 (1): 41-49.

Weifeng W, Xiangdong L, Zhihai M, Kneeshaw DD, Changhui P. 2011. Positive relationship between aboveground carbon stocks and structural diversity in spruce dominated forest stands in New Brunswick. Canada. For Sci 57: 506-515. DOI: 10.1093/forestscience/57.6.506.

Wu J, Liu W, Chen C. 2016. Below-ground interspecific competition for water in a rubber agroforestry system may enhance water utilization in plants. Sci Rep 6:19502. DOI: 10.1038/srep19502.

Ya-Huang L, Marc W, Cadotte MW, Burgess KS, Liu J, Shao-Lin T, Jia-Yun Z, Xu K, De-Zhu L, Lian-Ming G. 2019. Greater than the sum of the parts: how the species composition in different forest strata influence ecosystem function, Ecol Lett 22 (9): 1449-1461.

Yang B, Meng X, Singh AK, Wang P, Song L, Zakari S, Liu W. 2020. Intercrops improve surface water availability in rubber-based agroforestry systems. Agric Ecosyst Environ 298: 106937. DOI: 10.1016/j.agee.2020.106937.

Yang YH, Li P, Ding JZ, Zhao X, Ma WH, Ji CJ, Fang JY. 2014. Increased topsoil carbon stock across China's forests. Glob Chang Biol 20: 2687-2696. DOI:10.3390/f11030305.

Zhang J, Webster J, Powers RF, Mills J. 2008. Reforestation after the mountain fire in Northern California: an untold success story. J For 107: 425-430. 